\title{
Experimental Evaluation of Modified Photo Voltaic Method (MPVM) of Desalination System for Water Treatment
}

\author{
Chetan S. Kadlag', S. M. Gawande ${ }^{2}$ \\ ${ }^{1}$ Student, Anantrao Pawar College of Engineering Parvati Pune \\ ${ }^{2}$ Professor, Head Department of Civil Engineering APCOE
}

\begin{abstract}
Many countries in the terrain suffer from a shortage of natural fresh water. Increasing amounts of fresh water will be required in the future as a result of the growth in population rates and enhanced living standards, together with the expansion of industrial and agricultural activities. Achieving fresh-water resources from rivers and ground water are presently limited and are being increasingly depleted at an alarming rate in many places. As we know that about 97\% earth's water is sea water, $2 \%$ is entrapped in ice \& glaciers, and only $0.5 \%$ water is useful. A seawater desalination process separates saline seawater into two streams: a fresh water stream incorporating a low concentration of dissolved salts and a concentrated brine stream. A study of various desalination processes has been presented in the following project report. The suggested Desalination methods may in turn furnish the ever increasing demand of water \& may satisfy the needs of forthcoming generations. So growth of industrialization and population never been stopped as universe rule as far as possible we have to try to get maximum water from earth and as above mentioned sea water available is so large. As my project can help to next generation and industry to whole world. But as today India's concerned about desalination so bad. So can India also take interest in such technology will help in growth of country.
\end{abstract}

Keywords: Desalination, Pv System, Saline Water, Solar System, Radiations

\section{Introduction}

Water is one of the most copious resources on Earth, covering approximately Three quarters of the planet's surface. About $97 \%$ of the Earth's water is salt water in the oceans: $3 \%$ of all fresh water is in ground water, lakes and rivers, which supply most of that required by humans and animals. Water is essential to life. The importance of supplying potable water can hardly be overstressed. Man has been relying on rivers, lakes and underground waterreservoirs for fresh-water requirements in domestic life, agriculture and industry. However, rapid industrial-growth and the population explosion world-wide have resulted in a large escalation of the demand for fresh water. Added to this is the problem of pollution of rivers and lakes by industrial wastes and the large amounts of sewage discharged. On a global scale, man-made pollution of natural originator of water is becoming the single largest cause for fresh-water scarcity. Besides the only inexhaustible sources of water are the oceans. Their main difficulty, however, is the high salinity of such water. Many countries in the world suffer from a scarcity of natural fresh water. Increasing amounts of fresh water will be required in the future as a result of the rise in population rates and enhanced living standards, together with the expansion of industrial and agricultural activities. Available fresh-water resources from rivers and groundwater are presently limited and are being increasingly depleted at an alarming rate in many places.

Vast reserves of fresh water underlie the earth's surface, but much of it is too deep to access in an economically efficient manner. Additionally, seawater is unsuitable for human utilization and for industrial and agricultural uses. By removing salt from the virtually unlimited supply of seawater, desalination has emerged as an important source of fresh water. Today; some countries depend on desalination technologies for the purpose of meeting their fresh water requirements. In particular, in the Middle East, seawater desalination is a vital and dependable fresh water resource in countries such as Saudi Arabia, United Arab Emirates, and Kuwait. Furthermore, it is likely that desalination will continue to grow in popularity in the Middle East. Overall, it is estimated that over 75 million people worldwide obtain freshwater by desalinating seawater or brackish water.

Solar distillation has been practiced for many generations. Solar stills were the first to be used in large-scale, distilledwater production. The first water-distillation plant constructed was a system built at Las Salinas, Chile, in 1874.The still covered $4700 \mathrm{~m} 2$ and produced up to 23,000 liters of fresh water per day (4.9 litre/m2) in clear sky conditions. The still was operated for 40 years and only abandoned after a fresh-water pipe was installed to supply water to the area from the mountain region. The use of solar concentrators in solar distillation was reported by Pasteur (1928), who used a concentrator to focus solar rays onto a copper boiler containing water. The steam generated from the boiler was piped to a conventional water-cooled condenser in which distilled water was accumulated. Renewal of interest in solar distillation occurred soon after the First World War, during which several new devices had been developed, such as the roof-type, tilted-wick, inclinedtray and inflated stills. Solar energy can be used for seawater desalination either by producing the thermal energy required to drive the phase-change processes or by generating the electricity required to drive the membrane processes. Solar-desalination systems are thus classified into two categories, i.e. direct and indirect collection-systems. As their name implies, direct-collection systems use solarenergy to produce distillate directly in the solar collector, 


\section{International Journal of Science and Research (IJSR) \\ ISSN (Online): 2319-7064}

Index Copernicus Value (2013): 6.14 | Impact Factor (2014): 5.611

whereas in indirect collection systems, two sub-systems are employed (one for solar-energy collection and one for desalination). Conventional desalination systems are similar to solar systems because the same type of equipment is applied. The prime difference is that in the former, either a conventional boiler is used to provide the required heat or mains electricity is used to provide the required electric power, whereas in the latter, solar energy is applied. Water and energy are two inseparable commodities that govern the lives of humanity and promote civilization. The history of mankind proves that water and civilization are two inseparable entities. This is proved by the fact that all great civilizations were developed and Flourished near large sources of water. Rivers, seas, oases, and oceans have attracted mankind to their coasts because water is the source of life. History proves the importance of water in the sustainability of life and the development of civilization. Maybe the most significant example of this influence is the Nile River in Egypt. The river provided water for irrigation and mud full of nutrients. Ancient Egyptian engineers were able to master the river water and Egypt, as an agricultural nation, became the main wheat exporting country in the whole Mediterranean Basin. Due to the richness of the river, various disciplines of science like astronomy, mathematics, law, justice, currency and police were created at a time when no other human society held this knowledge.

\subsection{Definition of Desalination}

Seawater desalination is a process which separates saline seawater into two streams: a fresh water stream containing a low concentration of dissolved salts and a concentrated brine stream, fresh water further made available to satisfy human needs.

\subsection{Desalination Processes}

Following table shows various desalination processes:

Table 1

\begin{tabular}{|l|}
\hline 1.0Phase-change processes \\
\hline 1. Multi-Effect Flash (MEF) \\
\hline 2. Multiple Effect Boiling (MEB) \\
\hline 3. Vapour Compression (VC) \\
\hline 4. Freezing \\
\hline 5. Solar stills \\
\hline - conventional stills \\
- special stills \\
- wick-type stills \\
- multiple-wick-type stills \\
\hline 2.0Membrane processes \\
1. Reverse Osmosis (RO) \\
2. Electro Dialysis (ED) \\
\hline
\end{tabular}

\subsection{Process Selection}

During the design effect, there is a need to select a process suitable for a particular application. The factors to be considered during such a selection are:

1) Suitability of the process for solar-energy application.

2) The effectiveness of the process with respect to energy consumption.
3) The amount of fresh water required in a particular application in combination with the range of applicability of the various desalination-processes.

4) The sea-water treatment requirements.

5) The capital cost of the equipment.

6) The land area required, or could be made available, for the installation of the equipment.

\subsection{The Multi-Stage Flash Process}

The MSF process is composed of a series of elements called stages. In each stage, condensing steam is used to preheat the seawater feed. By fractionating the overall temperature differential between the warm source and seawater into a large number of stages, the system approaches ideal total latent heat recovery. Operation of this system requires pressure gradients in the plant. The principle of operation is shown in Fig. Current commercial installations are designed with $10-30$ stages $\left(2{ }^{\circ} \mathrm{C}\right.$ temperature drop per stage).A practical cycle representing the MSF process is shown in Fig. The system is divided into heat-recovery and heat rejection sections. Seawater is fed through the heat-rejection section, which rejects thermal energy from the plant and discharges the product and brine at the lowest possible temperature.

The feed is then mixed with a large mass of water, which is recirculated around the plant. This water then passes through a series of heat exchangers to raise its temperature. The water next enters the solar collector array or a conventional brine heater to raise its temperature to nearly the saturation temperature at the maximum system pressure. The water then enters the first stage through anorifice and in so doing has its pressure reduced. Since, the water was at the saturation temperature for a higher pressure, it becomes superheated and flashes into steam.

The vapour produced passes through a wire mesh (demister)to remove any entrained brine droplets and hence into the heat exchanger, where it is condensed and drips into a distillate tray.

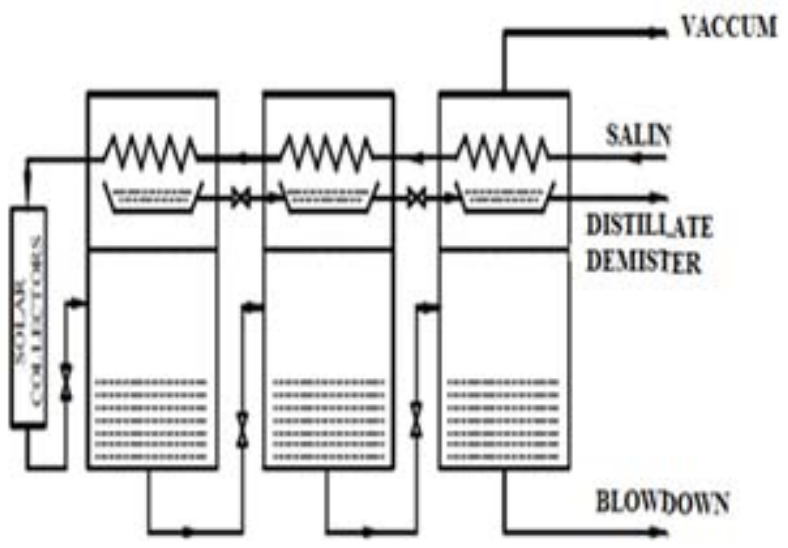

fig no.lPrinciple of operation of the multi-stage flasb(MSF)ş̧stem

\subsection{Reverse Osmosis}

Reverse Osmosis (RO) is proved to be the most reliable, cost effective, and energy efficient in producing fresh water compared to other desalination technologies. It is the fastest- 


\section{International Journal of Science and Research (IJSR) \\ ISSN (Online): 2319-7064 \\ Index Copernicus Value (2013): 6.14 | Impact Factor (2014): 5.611}

growing desalination technology with a greater number of installations around the world. The economic and technical performance of a medium-capacity RO desalination plant $(2,000 \mathrm{~m} 3 /$ day $)$ proposed to be installed in Umm Qatar city south of Basra, Iraq is analyzed using DEEP-3.2 software created by the International Atomic Energy Agency (IAEA). This port city is located on the Gulf shore and does not have any fresh water resources. The analysis shows that the cost of fresh water produced by this plant is US $\$ 0.986 / \mathrm{m} 3$ with a good quality of fresh water (279 ppm), which is a reasonable price for this remote area. The analysis also shows an increase in water production cost of about $12 \%$ at increased electricity price from 0.06 to $0.1 \mathrm{US} \$ / \mathrm{kWh}, 5.3 \%$ when the seawater salinity increased from 35,000 to $45,000 \mathrm{ppm}$, $2.5 \%$ when the seawater temperature decreased from 330 to $20 \mathrm{oC}$, and $0.71 \%$ when the interest rate increased from $0 \%$ to $5 \%$. Pumping fresh water from the Basra purification plant (located $175 \mathrm{~km}$ north of Umm Qatar) is 22.16 times the cost and $236.7 \%$ poorer quality than the fresh water produced by the RO plant.

If the pressure is increased above the osmotic pressure on the solution side of membrane, the flow is reversed and water flows from the concentrate to the dilute side, this is called Reverse Osmosis (RO).

\subsubsection{General Sequence of Reverse Osmosis}

- Water abstraction

- Pre-treatment

- Membrane separation unit

- Post-treatment

- Distribution

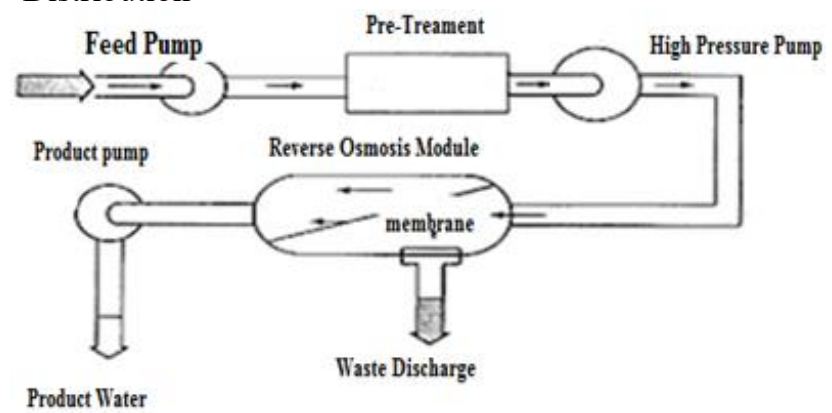

Figure: Reverse Osmosis layout

\subsection{Vapor Compression Distillation}

In the VCD process the heat for evaporating the seawater comes from the compression of vapor. The VCD plants take advantage of the principle of reducing the boiling point temperature by reducing the pressure. Two methods are used to condense water vapor to produce sufficient heat to evaporate incoming seawater: a mechanical compressor and a steam jet. The mechanical compressor is usually electrically driven. VCD units have been built in a variety of configurations to promote the exchange of heat to evaporate the seawater. The compressor creates a vacuum in the evaporator and then com- presses the vapor taken from the evaporator and condenses it inside of a tube bundle. Seawater is sprayed on the outside of the heated tube bundle where it boils and partially evaporates, producing more vapor. With the steam-jet type of VCD unit, called a thermo compressor, a venturi orifice at the steam jet creates and extracts water vapor from the evaporator, creating a lower ambient pressure. The extracted water vapor is compressed by the steam jet. This mixture is condensed on the tube walls to provide the thermal energy, heat of condensation, to evaporate the seawater being applied on the other side of the tube walls in the evaporator. The low temperature VCD distillation is a quite simple, reliable, and efficient process requiring power only. Having a high capacity compressor allows operation at low temperatures below $70^{\circ} \mathrm{C}$, which reduces the potential for scale formation and corrosion. The VCD process is generally used for small-scale desalination units. They are usually built up to the range of $3000 \mathrm{~m} 3 /$ day. The larger unites power consumption is about $8 \mathrm{~kW} \mathrm{~h} / \mathrm{m} 3$ of product water. VCD units are often used for resorts, industries, and drilling sites where fresh water is not readily available.

\subsection{Background to Reverse Osmosis and Solar Applications}

Reverse Osmosis is extensively applied in the water treatment industry. These applications include both the industrial sector as well as (to a lesser extent) the municipal sector. Reverse osmosis for the production of potable water is still not widely applied despite high feed TDS and low flow rate requirements being the prevailing characteristics for portable applications. The exception is of course the production of potable water from seawater by reverse osmosis, but this has thus far found limited application in South Africa. Reverse Osmosis has however found use in several small-town areas. Here, the treatment of brackish water, with typically high levels of hardness or Fluoride content, has been favored by Reverse Osmosis as opposed to Ion Exchange and other technologies. Typically the main water source for such towns is an active borehole or aquifer. Unfortunately, though there is an abundance of boreholes for possible treatment, these sites are often in remote areas with little or no infrastructure to install a reverse osmosis treatment unit. The South African Constitution dictates that every South African has the right to have access to potable water. The South Africa government has been especially active in the supply of water to township and rural areas, but the expansion of the electrical grid to supply electricity to all these areas is still lagging behind(1). Several alternative energy sources are being evaluated in the interim, with diesel, car batteries, LPG and paraffin power being the norm. However, these forms of energy can only be applied for low energy requirements, i.e. cooking and lighting requirements or at best the transport of potable water. These energy resources are however not viable for reverse osmosis systems where high energy requirements from the high pressure feed pumps add severe operating costs to the equation. For some time one of the most promising and a widely applied energy source has been the use of solar energy. Thus far solar power has, as with diesel, LPG and paraffin, also been applied to mainly cooking and lighting requirements with severe limitations on the size and application of typical cooking utensils. Here solar power is typically combined with wood, LPG, paraffin or diesel to supply refrigeration, cooking and other energy intensive applications. The development of reliable solar powered DC borehole pumps, has further helped with bringing water to the people. Several small installations, more than often in very remote areas, have made it possible to supply water 


\section{International Journal of Science and Research (IJSR) \\ ISSN (Online): 2319-7064}

Index Copernicus Value (2013): 6.14 | Impact Factor (2014): 5.611

from active boreholes to animals, farms and people. Unfortunately, the typical areas where the use of boreholes is required for the supply of water, are also those areas with very brackish water - not fit for human consumption. The next logical step is therefore, a water treatment unit, driven by solar power, to render the water potable.

\subsection{Solar RO Trials}

The development and implementation of a solar powered RO unit will not only be of great benefit for communities in rural areas; but is also seen as a cost effective method of supplying potable water from brackish sources, in disadvantaged and or remote areas. The concept is relevant to areas where small communities are spread over large areas, where the high cost of erecting large desalination plants and reticulation of desalinated water, or alternatively, the piping of freshwater from other sources, is neither practically nor economically viable. The use of solar panels, which generate the power required to drive the RO unit, constitutes an initial capital investment that can be written off over the lifetime of the unit. Results, gained from the test runs with the demonstration unit, will significantly contribute toward the optimization of future units and plants of increased capacity.

\section{Literature Survey}

1) Akili D. Khawaji, Ibrahim K. Kutubkhanah, JongMihn Wie carried out research on "Advances in seawater desalination technologies.

In that they studied that, a number of seawater desalination technologies have been developed during the last several decades to augment the supply of water in arid regions of the world. Due to the constraints of high desalination costs, many countries are unable to afford these technologies as a fresh water resource. However, the steady increasing usage of seawater desalination has demonstrated that seawater desalination is a feasible water resource free from the variations in rainfall. A seawater desalination process separates saline seawater into two streams: a fresh water stream containing a low concentration of dissolved salts and a concentrated brine stream. The process requires some form of energy to desalinate, and utilizes several different technologies for separation. Two of the most commercially important technologies are based on the multi-stage flash (MSF) distillation and reverse osmosis (RO) processes. Although the desalination technologies are mature enough to be a reliable source for fresh water from the sea, a significant amount of research and development (R\&D) has been carried out in order to constantly improve the technologies and reduce the cost of desalination. This paper reviews the current status, practices, and advances that have been made in the realm of seawater desalination technologies. Additionally, this paper provides an overview of R\&D activities and outlines future prospects for the stateof-the-art seawater desalination technologies. Overall, the current review is made with special emphasis on the MSF and RO desalination technologies because they are the most successful processes for the commercial production of large quantities of fresh water from seawater. From the above study, they concluded that A number of seawater desalination technologies have been introduced successfully during the last several decades to augment the water supplies in arid regions of the world. Due to the constraint of high desalination costs, many countries are unable to afford these technologies as a fresh water resource. Nevertheless, the adoption of seawater desalination technologies by some countries has demonstrated that seawater desalination certainly offers a new water resource free from variations in rainfall. Although the desalination technologies are mature enough to be a reliable source of fresh water from the sea, presently active $R \& D$ work is being performed by several institutions in order to constantly improve the technologies and reduce the cost of desalination Taking into consideration the importance of and promising potentials for desalination in the future in many countries, long term multidisciplinary and integrated R\&D programs are needed for the purpose of making the sea water desalination techniques affordable worldwide. Such comprehensive and collective R\&D programs would be required to develop in collaboration with the governments, industries, universities, and research institutions.

2.) Franz Trieba, Hans Müller-Steinhagena, Jurgen Kernb, Jurgen Scharfec, Malek Kabaritid, Ammar Al Taherd carried out research on "Technologies for large scale seawater desalination using concentrated solar radiation".

In that they studied the principles and the present state of the art of concentrating solar power technology and explains the option for seawater desalination, either using electricity or steam generated in such plants. The economic potential of this technology in the MENA region can cope with the present and the expected future demand of electricity and water. First projects are now being realized, for electricity and also for combined heat and power for desalination, electricity and cooling.

From the above study, they concluded that Concentrating solar power technology offers unique opportunity for competitive, secure and sustainable energy for electricity and seawater desalination in the Middle East and North Africa.CSP is present state of the art, the resources are almost unlimited, and the necessary investments are affordable. The resources exceed by far the present Middle East oil exports and are still untapped. While projects are already in operation or being built for electricity generation in the US and Spain, the basic engineering of a first plant for the combined generation of electricity and heat for power, cooling and seawater desalination started in Aqaba, Jordan in 2007. It will be the first economically competitive solar power station without any financial public support.CSP is of vital importance for the MENA region, as it is the only available resource that is large and affordable enough to cope with the challenge of growing electricity consumption and increasing shortage of potable water. It will, however, take at least a decade to introduce noticeable CSP shares into the energy portfolio. Therefore, MENA governments must establish adequate conditions to initiate market introduction now.

\section{Solar Energy}

There are a variety of technologies that have been developed to take advantage of solar energy. These include: 


\section{International Journal of Science and Research (IJSR) \\ ISSN (Online): 2319-7064 \\ Index Copernicus Value (2013): 6.14 | Impact Factor (2014): 5.611}

Photovoltaic (solar cell) systems: Producing electricity directly from sunlight. Concentrating solar systems: Using the sun's heat to produce electricity.

Passive solar heating and day lighting: Using solar energy to heat and light buildings. Solar hot water: Heating water with solar energy. Solar process heat and space heating and cooling: Industrial and commercial uses of the sun's heat.

\subsection{Photovoltaic Cells}

Photovoltaic (PV) cells, the solar cells typically applied to power calculators and watches, convert sunlight directly into electricity. These cells are made of semi-conducting materials similar to those used in computer chips. When these materials absorb sunlight, the solar energy release electrons from their atoms, allowing the electrons to flow through the material to produce electricity. This process of converting light (photons) to electricity (voltage) is called the photovoltaic effect. PV cells are typically combined into modules that hold many cells; two or more of these modules are mounted in PV arrays that can measure up to several meters on a side. These flat-plate PV arrays can be mounted at a fixed angle facing north, or they can be mounted on a tracking device that follows the sun, allowing them to capture the most sunlight over the course of a day. About 2 to $3 \mathrm{PV}$ arrays can provide enough power to run a borehole pump; and even more for a large electric utility or industrial application. Some PV cells are designed to operate with concentrated sunlight. These cells are built into concentrating collectors that use a lens to focus the sunlight onto the cells. This approach has both advantages and disadvantages compared with flat-plate PV arrays. The main idea is to use very little of the expensive semi-conducting PV material while collecting as much sunlight as possible. But because the lenses must be pointed at the sun, the use of concentrating collectors is limited to the sunniest parts of the country. Some concentrating collectors are designed to be mounted on simple tracking devices, but most require sophisticated tracking devices, which further limit their use for electric utilities, industries and large buildings.

The performance of a PV cell is measured in terms of its efficiency at turning sunlight into electricity. Only sunlight of certain energy will work efficiently to create electricity, and much of it is reflected or absorbed by the materials that make up the cell. Because of this, a typical commercial PV cell has an efficiency of $15 \%$ - about one-sixth of the sunlight striking the cell generates electricity. Low efficiencies mean that larger arrays are needed, resulting in higher costs. Improving PV cell efficiencies, while holding down the cost per cell, is an important goal of the PV industry and they have made significant progress. The first PV cells, built in the 1950 s, had efficiencies of less than $4 \%$.

\section{Experimental Equipment and Site}

\subsection{Reverse Osmosis Unit}

The reverse osmosis unit that was used for the pilot tests consisted of the following equipment:

Pressure release valve

10 " cotton wound 5 cartridge filter
Two 2 1/2" membrane pressure vessels

Two 2 1/2" LP membranes Permeate flow indicator Brine flow indicator Membrane inlet pressure gauge Membrane outlet pressure gauge Backpressure control valve

Piping Portable $\mathrm{pH}$ and conductivity meters the overall (boxed) dimensions of the unit is $(\mathrm{L} \mathrm{x} \mathrm{W} \mathrm{x} \mathrm{H)} 1300 \mathrm{x} 600 \mathrm{x}$ $600 \mathrm{~mm}$.

The following specifications are relevant to the LP membranes used for the Solar RO unit:

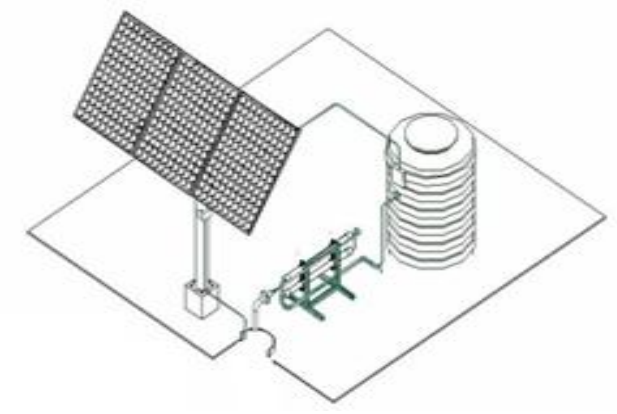

Table 2: 21/2"LPMembraneSpecifications

\begin{tabular}{|c|c|}
\hline Characteristic & Specification \\
\hline Model No & FLU 2540 LP \\
\hline Length & $40 "$ \\
\hline Diameter & $21 / 2 "$ \\
\hline Flow (min / nom / max) & $100 / 118 / 1391 / \mathrm{h}$ \\
\hline
\end{tabular}

\subsection{Solar Unit}

\section{Solar Panels}

The solar power supply consisted of a solar panel consisting of three Siemens Solar Pro Charger ${ }^{\circledR}$ JF Solar Electric Modules. The following specifications apply to the modules used:

Table 3: Solar Module Specifications

\begin{tabular}{|c|c|}
\hline Characteristic & Specification \\
\hline New Model No & SP75 \\
\hline Configuration & $12 \mathrm{~V}$ \\
\hline Rated Power & $75 \mathrm{~W}$ \\
\hline Min Power ( $_{\min }$ ) & $70 \mathrm{~W}$ \\
\hline Open Circuit Voltage (Voc) & $2.7 \mathrm{~V}$ \\
\hline Short Circuit Current (Isc) & $4.8 \mathrm{~A}$ \\
\hline Voltage as Load & $17 \mathrm{~V}$ \\
\hline Current at Load & $4.4 \mathrm{~A}$ \\
\hline Current at NOC & $3.5 \mathrm{~A}$ \\
\hline Cell Type & Mono \\
\hline Max System Voc & $600 \mathrm{~V}$ \\
\hline Length & $1200 \mathrm{~mm}$ \\
\hline Width & $527 \mathrm{~mm}$ \\
\hline Depth & $34 \mathrm{~mm}$ \\
\hline Weight & $7.6 \mathrm{~K} . \mathrm{g}$ \\
\hline
\end{tabular}

\section{Experimental Site Preparation and Arrangement}

\subsection{Preparation before Going to Site}

The following sites were used to conduct tests for the Solar RO unit: 


\section{International Journal of Science and Research (IJSR) \\ ISSN (Online): 2319-7064 \\ Index Copernicus Value (2013): 6.14 | Impact Factor (2014): 5.611}

\section{Sangamner Urban Area}

The typical site preparation consisted of pre-sampling the borehole and to analyze at least the following:

TDS / Conductivity $\mathrm{pH}$

Total Hardness M - Alkalinity

Iron Silica

In addition to these, analyses also included $\mathrm{Ca}^{2+}, \mathrm{Mg}^{2+}, \mathrm{Na}^{+}$, $\mathrm{Cl}^{-}, \mathrm{SO}_{4}{ }^{2-}, \mathrm{Mn}^{2+}$ and $\mathrm{F}^{-}$. The results were used to run $\mathrm{RO}$ projection software to determine scaling potential and maximum operating recovery.

The sites that offered representative water analyses (typical TDS for the area), without causing problems with high scaling potential, were used to evaluate the solar unit. The objective of the study was not to evaluate the performance of several membranes and anti -scalant chemicals, but to rather identify a good representative membrane that could operate under a variety of conditions. The end user of the Solar RO system will have to identify the scaling potential of his/her water by independent analyses and decide whether antiscalant chemicals or other forms of chemical treatment will be required to increase production or stabilize the product water.

\subsection{Preparation on Site}

The procedure for site preparation included the following:

1)Setting up of the solar panel to maximize the angle with the sun. The knowledge of the locals was used to identify the sun's track in the specific season. The solar panel was fixed such that it was sturdy and not able to be moved by wind or other factors. The panel was erected at an optimum angle to maximize sunlight on the panel. Attention was given to safety when using large equipment and electrical components.

2) Connection of the RO plant to the water supply. The submersible pump was connected to the membrane plant with flexible polypropylene agricultural hose. A pressure release valve, set at 10 bar was installed upstream of the cartridge filter to protect the pump diaphragm from overpressure while maintaining the system within the cartridge filter housinges pressure rating.

3) Startup of the RO plant. The system was started with the backpressure control valve fully open to minimise recovery. The valve was slowly closed in order to reach the predetermined recovery setting for the water.

4)Monitoring of the unit. All the system parameters were continually monitored to optimize the production conditions. Certain tests were run at one "fixed" setting to determine production capacity under stand-alone conditions without operator intervention.

\subsection{Operation and Test Conditions}

The following parameters were monitored and evaluated as being relevant to the efficient operation of the unit:

Level of Sunlight

Feed Conditions of Well Water

Permeate Product Quality and Production Brine Effluent

Quality and Production

Auxiliary Process Data for Optimized Production.
The following test conditions were identified to simulate or evaluate real life conditions:

1) Variation in location. The sites were representative of an area where the unit could be applied in future.

2) Variation in feed water conductivity. The sites had a range of water qualities. Laboratory exercises were required to add additional high conductivity experiments.

3) Variation in season. The test runs were completed from autumn to early summer.

4) Variation in daytime. The test runs were conducted throughout the day in order to establish a "Time of Day" profile for unit production.

The data realised a product-per-day figure that revealed an average production of permeate under different operating conditions.

\section{Operability and Maintenance}

The unit proved to be durable and could easily stand up to abuse. The unit was fairly easy to set up, with initial manpower required for the solar panels. Although these panels are not to heavy, they are quite large and one does need assistance during site preparation. The RO unit itself is comfortably handled by two people and showed no signs of wear and tear.

\section{Conclusions}

The Solar RO unit performed well under all the conditions that were evaluated. The unit proved to be easy to operate, very durable, with little maintenance required. Additional operator input did however prove to increase production even though stand-alone operation rendered excellent production figures.

\section{References}

[1] A.D. Khawaji, T. Khan and J.M. Wie, "Gas Turbine Operating Experience in a Power/Seawater Desalination Cogeneration Mode", ASME ASIA,97 Congress \& Exhibition, Singapore, September 30-October2, 1997.

[2] E. Delyannis, "Historic background of desalination and renewable energies," Solar Energy, 75(5) (2003)357366.

[3] M. Pascoe." Desalination. "Australian State of the Environment Committee, Report, 2006.

[4] Koroneos C, Dompros A, Roubs G. "Renewable energy driven desalination system modeling". Journal of Cleaner Production, 2007.

[5] Thomson M, Infield D. "A photovoltaic-powered seawater reverse-osmosis system without batteries." Desalination, 2003. 